\title{
Reovirus RNA
}

National Cancer Institute

\section{Source}

National Cancer Institute. Reovirus RNA. NCI Thesaurus. Code C129669.

The viral RNA that originates from a reovirus. 